\title{
PRODUCING OF BEEF MEAT ENRICHED WITH ORGANICALLY BOUND SELENIUM
}

\author{
Lj. Sretenović, ${ }^{1}$ Ž. Novaković ${ }^{1}$ M. M. Petrović ${ }^{1}$, M. Todorović ${ }^{2}$, \\ V.Pantelić ${ }^{1}$, S.Aleksić ${ }^{1}$, M. Petričević ${ }^{1}$ \\ ${ }^{1}$ Institute for Animal Husbandry, Autoput 16, 11080 Belgrade, Serbia \\ ${ }^{2}$ University of Belgrade-Faculty of Agriculture, Nemanjina 6, 11080 Beograd-Zemun \\ Corresponding author: sretenlj@gmail.com \\ Original scientific paper
}

\begin{abstract}
In this study, the effects of the organic and inorganic form of selenium, in the diet for finishing beef cattle, were investigated. Sell-Plex produced by American firm Alltech as a source of organic selenium with selenium concentration of $2000 \mathrm{mg} / \mathrm{kg}$ was used. The source of inorganic selenium was sodium selenite. The trial was conducted on Simmental fattening cattle in the final stage in the free housing system and it lasted 60 days. Selenium content in control and trial group (m. longissimus dorsi) was 78.65 and $125.03 \mu \mathrm{g} / \mathrm{kg}(\mathrm{P}<0.01)$, in kidneys 855.52 and $1026.04 \mu \mathrm{g} / \mathrm{kg}(\mathrm{P}<0.001)$; in liver 453.13 and $534.64 \mu \mathrm{g} /$ $\operatorname{kg}(\mathrm{P}<0.01)$ and in spleen 308.44 and $383.62 \mu \mathrm{g} / \mathrm{kg}(\mathrm{P}<0.001)$, respectively. There were no differences in main carcass characteristics, share of some tissues in the round and three rib chops, chemical composition and meat quality of $\mathrm{m}$. longissimus dorsi $(\mathrm{P}>0.05)$. Considering the higher storage of organic selenium in meat and internal organs of the fattening cattle with respect to the inorganic form, it was concluded that the selenium supply in organic form has a better bioavailability. Inclusion of organic selenium into the diet in the final stage of fattening cattle and its deposition in meat and internal organs is a good and easy way to get meat with functional foods properties that in addition to nutritional value should positively affect human health.
\end{abstract}

Key words: selenium, beef cattle, meat, carcass characteristics

\section{Introduction}

The meat enriched with selenium belongs to the so-called functional foods. The term "functional food" includes the food stuffs which beside their basic, main nutritive value, contain the essential substances with potential positive effects on body and mental health. More precisely, this food should consist of functional food nutrients with certain specific properties, they are main part of every day nutrition 
and exclusively of natural origin, i.e. they cannot consist of tablets, capsules, solutions, powders, etc. It should contribute to improvement of body functions, increase of immunity, faster recovery from diseases, slowing of the aging process, etc. Functional food should contain ample functional food stuffs, adequate amounts of food should be consumed, food should be diverse and with uniform presence in nutrition (Sretenović et al., 2009; Sretenović et al., 2007). This concept was introduced in Japan in the eighties of the last century.

Selenium (Se) is an essential trace element for human and animal health that participates in a number of reactions that are vital for living cells. It is known that it is unevenly distributed on the Earth with low selenium regions predominating. To prevent selenium-deficiency diseases in livestock, additions of selenium to animal feed are required but it is important what form of this trace element is used. Until recently Se in the form of sodium selenite was added to the feed which drain into the meat, milk and eggs that are contain less selenium than from animals receiving it as seleno-methionine, the chief natural nutritional form of the element present in grain crops grown in selenium-adequate regions, or from high-selenium yeast (Lyons et al. 2007; Sretenović et al., 1999; Sretenović et al., 2003; Sretenović et al. 2008). Since the selenium content in plant-based food depends on its availability from soil, the level of this element in human (or food animal) foods varies among regions. In general eggs and meat are considered to be good sources of Se in the human diet. When considering ways to improve human selenium intake, there are several potential options. These include: • direct supplementation $\bullet$ soil fertilization $\bullet$ supplementation of food staples such as flour $\bullet$ production of Se-enriched functional foods. - It seems likely that a fourth strategy, production of 'functional foods' enriched with selenium, deserves more attention (Surai, 2006; Omprakash et al., 2011). Indeed, analysis of the current literature indicates that an enrichment of eggs, meat and milk with Se is a valuable option to improve the Se status of the general population, production of these kinds of animal-derived food foodstuffs is a natural way to health promotion. Therefore Seenrichment of eggs, meat and milk is simply the production of naturally-designed food ingredients. Indeed, production and commercialization of such organic Se sources such as selenized yeast (for example Sell-Plex) opened a new era in Se supplementation of animals and has provided an opportunity for producers to meet the growing requirements of the consumer. It is indeed possible to provide consumers with a range of animal-derived products with nutritionally modified composition in such a way that they can deliver substantial amounts of healthpromoting nutrients, such as selenium, to improve the general diet and to help maintain good health.

Selenium is present in the body in small amounts, the largest amounts of selenium are found in the liver and erythrocytes. The main role of selenium is for synthesis enzymes involved in neutralizing the harmful effects of free radicals and protect cell membranes from peroxide oxidation. It is well known that selenium is 
involved in the creation of tocopherols, which plays a major role in redox reactions, and to act synergistically with selenium (Nicholson et al., 1991).Selenium helps in reducing the risk of heart disease and participates in protection against various cancers, helps maintain the elasticity of tissues, increases sperm count and male fertility. It is not yet determined exactly what are the daily selenium requirements in humans, but many researchers agree that the amount of healthy adults of $50-70 \mu \mathrm{g}$ is sufficient for normal function. Daily intake of selenium depends on age, sex and physiological state. It is known that for pregnant women, nursing and convalescent need a higher intake than the average healthy adult man. There is evidence that the intake of selenium in most of the world below $200 \mu \mathrm{g}$ per day. Based on years of research Clark et al. (1998) indicated that the intake $200 \mu \mathrm{g}$ of selenium a day reduced the likelihood of cancer by $50 \%$.

Aim of this work was to compare the effects of different Se sources (organic selenium vs. inorganic- sodium selenite) on the amounts recovered in edible tissues i.e. muscles and organs (liver, kidney and spleen), carcass characteristics and physical-chemical characteristics of beef meat.

\section{Material and Methods}

Research was carried out on two groups (control $-\mathrm{C}$ with inorganic and trial-T with organic selenium) of finishing cattle with 15 heads in each group and it lasted 60 days. The trial was performed on Simmental cattle breed in the free/loose system of housing in strictly controlled nutrition and breeding system at the experimental farm of the Institute of Animal Husbandry. Both groups were fed identical diets based on whole maize silage and concentrate mixture which is in accordance to contemporary feeding norms $(N R C, 2001)$ for this cattle breed.

Composition of concentrate mixture was following (\%): corn grain - 67.8; wheat meal - 10.0; sunflower meal -16.0; limestone -1.4; mono-calcium phosphate3 ; salt -0.8 and mineral-vitamin pre-mixture -1.0 . The diet contained: $10.177 \mathrm{~kg}$ dry matter; $80.490 \mathrm{MJ}$ NEM -(Net energy for meat); 11.935 OFU-(Oat feed unit); $1199 \mathrm{~g}$ total proteins $(11.78 \%$ of dry matter); $1250 \mathrm{~g}$ crude fibre $(12.28 \%$ of dry matter). Both groups of animals were fed identical diet consisting of $12 \mathrm{~kg}$ of whole maize silage and $7.5 \mathrm{~kg}$ of concentrate mixture. Every head received $0,3 \mathrm{mg}$ $\mathrm{Se} / \mathrm{kg}$ dry matter but the only difference between groups was in the form of Se, i.e. organic vs. inorganic.

Sell-Plex as a source of organic selenium with $2000 \mathrm{mg} \mathrm{Se} / \mathrm{kg}$ was used. Sodium selenite was a source of inorganic selenium. At the end of fattening all heads were weighed before slaughtering and slaughtered in experimental slaughterhouse of the Institute. Left carcass sides was cut into pieces according by "Rulebook on the quality of meat of animal for slaughter, poultry and wildlife" (1974). 
The main carcass characteristics, share of muscle, fat, bone and joint tissue in round and trim from the 9-10-11 rib section, chemical composition and meat quality of $\mathrm{m}$. longissimus dorsi (MLD) were determined in the laboratory of Institute for Animal Husbandry. Also, samples of MLD and internal organs (liver, spleen and kidney) were collected and their Se content was detected by atomic absorption spectrophotometry (AAS).

Chemical composition of meat was done using SRPS ISO standardized methods: water content - SRPS ISO 1442:1998; content of mineral substances - SRPS ISO 936:1999; protein content - SRPS ISO 937:1992; content of intramuscular fat SRPS ISO 1444:1998. Colour of meat was determined by measuring of concentration of total pigments on spectrophotometer using method according to Horsney. Tenderness of meat was determined according to Volodkevitch. The $\mathrm{pH}$ value was determined by using a $\mathrm{pH}$ meter of a glass electrode. M. longissimus dorsi muscle area was measured using polar planimeter (Reiss Precision 3005, Germany). The scale for the classification of carcass was classified by assessment respectively of conformation and fat cover according by Council Regulation (EEC) No. 208/81; Council Regulation (EEC) No. 2930/81 and Council Regulation (EEC) No. 1026/91. (Community scale for the classification of carcases of adult bovine animals ( $w w w . o f f i c e-e l e v a g e . f r / p u b l i c a t i o n s / c l a s s e m e n t / b o v i n g b . p d f$ )

The data from the experiment were developed statistically by using the computer program "Statistical package for the social science "(SPSS., Ver.15.0, 2006).

\section{Results and Discussion}

Table 1. Organ weights and tissue Se distribution in finishing steers

\begin{tabular}{|l|c|c|c|c|}
\hline \multirow{2}{*}{ Item } & \multicolumn{2}{|c|}{ Tr e a t m e $\mathrm{n}$} & \multirow{2}{*}{ SEM $^{\mathrm{c}}$} & \multirow{2}{*}{$\mathrm{P}^{- \text {value }^{\mathrm{a}}}$} \\
\cline { 2 - 3 } Kidney & $\mathrm{T}$ & & & \\
\hline Weight, $\mathrm{kg}$ & 1.08 & 1.07 & 0.03 & 0.85 \\
\hline Weight, $\mathrm{kg} / \mathrm{kg} \mathrm{WBS}{ }^{\mathrm{b}}$ & 0.19 & 0.18 & 0.03 & 0.62 \\
\hline Se, $\mu \mathrm{g} / \mathrm{kg}$ & 1026.04 & 855.52 & 0.02 & $\mathrm{P}<0.001$ \\
\hline Liver & & & & \\
\hline Weight, $\mathrm{kg}$ & 6.62 & 7.00 & 0.31 & 0.18 \\
\hline Weight, $\mathrm{kg} / \mathrm{kg}$ WBS & 1.15 & 1.21 & 0.29 & 0.26 \\
\hline Se, $\mu \mathrm{g} / \mathrm{kg}$ & 534.64 & 453.13 & 0.16 & $\mathrm{P}<0.01$ \\
\hline Spleen & & & & \\
\hline Weight, $\mathrm{kg}$ & 1.100 & 1.17 & 0.25 & 0.65 \\
\hline Weight, $\mathrm{kg} / \mathrm{kg}$ WBS & 0.19 & 0.20 & 0.02 & 0.56 \\
\hline Se, $\mu \mathrm{g} / \mathrm{kg}$ & 383.62 & 308.44 & 0.02 & $\mathrm{P}<0.001$ \\
\hline Muscle-Musculus longissimus dorsi & & & & \\
\hline Se, $\mu \mathrm{g} / \mathrm{kg}$ & 125.03 & 78.65 & 0.11 & $\mathrm{P}<0.01$ \\
\hline
\end{tabular}

${ }^{\mathrm{a}}$ Differences were considered as significant at the level of 0.05 or less. ${ }^{\mathrm{b}} \mathrm{Weight}$ before slaughter

${ }^{\mathrm{c}} \mathrm{SEM}=$ standard error of the means 
Table 1. shows the selenium content in m. longissimus dorsi and internal organs. The results from this table indicate that selenium content in liver in experimental and control group was 534.64 and $453.13 \mu \mathrm{g} / \mathrm{kg}(\mathrm{P}<0.01)$; in spleen 383.62 and $308.44 \mu \mathrm{g} / \mathrm{kg}(\mathrm{P}<0.001)$ while the accumulation of selenium in kidney was the highest and amounted to 1026.04 and $855.52 \mu \mathrm{g} / \mathrm{kg}(\mathrm{P}<0.001)$, respectively. The content of selenium in $\mathrm{m}$. longissimus dorsi was much lower compared to its content in internal organs and amounted to 125.03 and $78.65 \mu \mathrm{g} /$ $\mathrm{kg}(\mathrm{P}<0.01)$, in the same order of top treatment.

The distribution pattern found in this experiment was consistent with the data of other authors although absolute values are different. The results regarding tissue Se concentrations are similar to data summarized by Combs and Combs (1986), which indicate that Se concentrations usually rank the highest in the kidney, intermediate in liver, and least in skeletal muscle. Also, our results show an identical trend to those obtained by Lower et al (2004) who examined the content of selenium in the kidneys, liver, spleen and m. semitendinosus. The higher efficacy of organic selenium was confirmed also by results of analyses of selected tissues published by Ortman and Pehrson (1997) as well as Knowles et al. (1999) who investigated blood, liver and milk selenium concentrations in cows receiving selenium yeast. Simek et al. (2002) fed diets supplemented with $4 \mathrm{mg} / \mathrm{d}$ Se yeast to bulls for 0,7 , or $30 \mathrm{~d}$ before slaughter and reported increases in muscle $\mathrm{Se}$ concentrations from 0.345 to 0.542 and $0.719 \mathrm{mg} / \mathrm{kg}$, respectively.

Our results are agreed with those obtained by Richards et al.(2011) who pointed out that supplementing $0.34 \mathrm{mg} / \mathrm{kg}$ Se in dry matter from Se yeast to a basal feedlot diet with adequate Se does not increase fattening performances but does result in increased tissue Se concentrations that do not exceed a range determined as normal. There were no differences $(\mathrm{P}>0.10)$ in body weight, average daily intake, dry matter intake, feed efficiency, or any carcass measures were detected. Muscle and liver Se concentrations were lower $(\mathrm{P}<0.01)$ for basal feedlot diet than for Se yeast diet. In the study of Antunović et al., (2009) it was concluded that $\mathrm{Se}$ in organic form had a better bioavailability compared to the inorganic. Namely, they evaluate the bioavailability of different Se sources on fattening lambs (diet without Se addition (control, C), or with a supply of $0.03 \%$ sodium selenite (IS) or $0.03 \%$ of organic selenium (OS; Sel-PlexTM). Growth performances were not affected by treatment but with respect to $C$, OS significantly increased $\mathrm{Se}$ content of blood $(\mathrm{P}<0.01)$, liver $(\mathrm{P}<0.01)$ and GSH-Px enzyme activity $(\mathrm{P}<0.01)$. OS also significantly increased blood $(\mathrm{P}<0.01)$ and liver $(\mathrm{P}<0.05)$ Se content with respect to IS. Also, the effects of different types of Se supplementation on the selenium concentration of beef, bovine internal organs and some other tissues were studied by Ekholm et al., (1991). The animals were kept in four dietary groups and fed on rations containing either $0.03 \mathrm{mg} \mathrm{Se} / \mathrm{kg}$ (basic level in local feeds), $0.25 \mathrm{mg}$ inorganic Se supplemented as sodium selenite, or $0.25 \mathrm{or} 0.4 \mathrm{mg} / \mathrm{kg}$ plant Se in dry matter from feed produced by spraying with sodium selenite. Se supplementation 
significantly increased the Se concentration of all tissue samples. The maximum response was caused by the diet containing $0.40 \mathrm{mg} / \mathrm{kg}$ plant. In general, plant Se raised the Se level more effectively than inorganic Se.

Table 2. The main carcass characteristics

\begin{tabular}{|l|l|c|c|c|c|}
\hline No & Item & $\mathrm{C}$ & $\mathrm{T}$ & SEM $^{\mathrm{b}}$ & P-value $^{\mathrm{a}}$ \\
\hline 1. & Pre-slaughter body weight, kg & 581.5 & 577.0 & 4.07 & 0.63 \\
\hline 2. & Hot carcass weight with kidney fat, $\mathrm{kg}$ & 337.4 & 328.2 & 3.10 & 0.18 \\
\hline 3. & Yield of hot carcass weight with kidney fat , \% & 58.03 & 56.86 & 0.28 & 0.08 \\
\hline 4. & Hot carcass weight without kidney fat, kg & 334.62 & 325.0 & 3.06 & 0.16 \\
\hline 5. & Yield of hot carcass weight without kidney fat \% & 57.53 & 56.31 & 0.28 & 0.06 \\
\hline 6. & Cold carcass weight without kidney fat, kg & 328.21 & 318.8 & 3.07 & 0.17 \\
\hline 7. & Yield of cold carcass weight without kidney fat, \% & 56.47 & 55.25 & 0.30 & 0.06 \\
\hline 8. & Kidney fat, kg & 2.82 & 3.18 & 0.06 & 0.67 \\
\hline 9. & Kidney fat yield, \% & 0.49 & 0.55 & 0.11 & 0.61 \\
\hline 10. & Carcass conformation, points & 4.08 & 4.23 & 0.09 & 0.49 \\
\hline 11. & Carcass dressing score, points & 3.09 & 4.00 & 0.19 & 0.06 \\
\hline 12. & Round dressing score, points & 3.33 & 3.90 & 0.20 & 0.11 \\
\hline 13. & Fat colour, points & 3.70 & 4.50 & 0.32 & 0.06 \\
\hline
\end{tabular}

${ }^{\mathrm{a}}$ Differences were considered as significant at the level of 0.05 or less. ${ }^{\mathrm{b}} \mathrm{SEM}=$ standard error of the means

In Table 2, the more important features of carcass are presented. The main characteristics of carcasses were determined according to International reference procedure for cattle carcass description and for dissection procedure to determine carcass composition in terms of muscle, fat and bones: Council Regulation (EEC) No. 1208/81; Council Regulation (EEC) No. 2930/81; Council Regulation (EEC) No.1026/91.

Results from this table show that inclusion of organic selenium in diets for beef cattle compared with inorganic form did not affect the final body weight of steers $(577.0$ and $581.5 \mathrm{~kg}$ ), the yield of hot carcass without kidney fat (56.31 and $57.53 \%$ ) and cold carcass without kidney fat (55.25 and 56.47\%), the amount of kidney fat $(3.18$ and $2.82 \mathrm{~kg}$ ), respectively, as well as carcass conformation, carcass and round dressing score and color of fat which is important in terms of sustainability for the sale and the visual appearance of the customer.

The distribution pattern found in our experiments was consistent with the data of Lawler et al., (2004) described the effects of feeds naturally high in Se on production, carcass characteristics, and Se distribution in terminal tissues. When providing dietary Se at supra-nutritional levels, source of Se did not affect production (intake of dry matter and average daily gain did not differ $\mathrm{P}>0.13$ ) or carcass characteristics (no differences ( $\mathrm{P}>0.12$ ) were noted for hot carcass weight, organ weights, $\mathrm{m}$. longissimus dorsi, back fat thickness, marbling scores, or quality 
and yield grade), but it altered the distribution and concentration of Se throughout the tissues of finishing beef steers.

Table 3. The share of muscle, fat, bone and connective tissue in round and trim from the 9-1011 rib section

\begin{tabular}{|c|l|c|c|c|c|}
\hline No & Item & $\mathrm{C}$ & $\mathrm{T}$ & SEM $^{\mathrm{b}}$ & P-value $^{\mathrm{a}}$ \\
\hline 1. & Round weight & 47.81 & 45.87 & 0.65 & 0.18 \\
\hline 2. & Muscle tissue, kg & 38.95 & 36.77 & 0.63 & 0.25 \\
\hline 3. & Muscle yield, \% & 81.45 & 80.16 & 0.62 & 0.36 \\
\hline 4. & Fat tissue, kg & 2.65 & 2.74 & 0.74 & 0.59 \\
\hline 5. & Fat yield, \% & 5.52 & 5.68 & 0.72 & 0.92 \\
\hline 6. & Bones, kg & 6.15 & 6.29 & 0.75 & 0.86 \\
\hline 7. & Bones yield, \% & 12.87 & 13.7 & 0.23 & 0.10 \\
\hline 8. & 9-10-11 rib section weight, kg & 4.08 & 3.95 & 0.10 & 0.55 \\
\hline 9. & Muscle tissue, kg & 2.74 & 2.69 & 0.07 & 0.36 \\
\hline 10. & Muscle yield, \% & 67.33 & 68.34 & 0.82 & 0.72 \\
\hline 11. & Fat tissue & 0.43 & 0.42 & 0.98 & 0.73 \\
\hline 12. & Fat yield, \% & 10.76 & 10.73 & 0.77 & 0.99 \\
\hline 13. & Connective tissue, kg & 0.06 & 0.06 & 0.10 & 0.55 \\
\hline 14. & Connective yield, \% & 1.49 & 1.64 & 0.09 & 0.46 \\
\hline 15. & Bones, kg & 0.81 & 0.75 & 0.19 & 0.49 \\
\hline 16. & Bones yield, \% & 19.85 & 18.81 & 0.64 & 0.61 \\
\hline
\end{tabular}

${ }^{a}$ Differences were considered as significant at the level of 0.05 or less. ${ }^{b} \mathrm{SEM}=$ standard error of the means

Dissection of the round and three rib chops i.e. proportion of muscle, connective tissue and bone is presented in Table 3. Organically bound Se had no effect on the share of muscle, fat, bone and connective tissue in the round and trim from the three rib chops, which is in agreement with results obtained by Lawler et al. (2004).

Table 4. Chemical composition and meat quality of $\mathrm{m}$. longissimus dorsi

\begin{tabular}{|l|l|c|c|c|c|}
\hline No & Item & $\mathrm{C}$ & $\mathrm{T}$ & SEM $^{\mathrm{b}}$ & P-value $^{\mathrm{a}}$ \\
\hline 1. & Moisture, \% & 75.74 & 75.90 & 0.11 & 0.51 \\
\hline 2. & Inter-muscular fat, \% & 1.31 & 1.10 & 0.12 & 0.41 \\
\hline 3. & Protein, \% & 21.76 & 21.83 & 0.11 & 0.77 \\
\hline 4. & Mineral matter, \% & 1.17 & 1.16 & 0.01 & 0.72 \\
\hline 5. & Cooking loss, \% & 41.31 & 41.14 & 0.32 & 0.81 \\
\hline 6. & Tenderness, \% & 13.28 & 14.12 & 0.91 & 0.69 \\
\hline 7. & Total pigments, $\mathrm{mg} / \mathrm{kg}$ & 6.66 & 147.15 & 6.15 & 0.66 \\
\hline 8. & pH (45 min) & 5.52 & 5.53 & 0.03 & 0.64 \\
\hline 9. & pH (24h) & 105.33 & 103.47 & 3.20 & 0.86 \\
\hline 10. & Longissimus muscle area, $\mathrm{cm}^{2}$ & 1.33 & 1.00 & 0.14 & 0.13 \\
\hline 11. & Marbling, points & & & \\
\hline
\end{tabular}

${ }^{\mathrm{a}}$ Differences were considered as significant at the level of 0.05 or less. ${ }^{\mathrm{b}} \mathrm{SEM}=$ standard error of the means 
In Table 4, the most important quality parameters of m. longissimus dorsi i.e. its chemical composition and some important technological characteristics are presented.

It is undisputed that selenium is an essential microelement for health care, improving the production and reproduction traits in humans and domestic animals. In the literature there are a lot of data about the importance of selenium sources and effects of organic and inorganic selenium on these traits, but very small ones that are most detailed information related to dissection. At this point we compare the data of our study with those obtained by other authors.

Results presented in Table 4 indicate that there were no significant differences for control and experimental group $(\mathrm{P}>0.05)$ relating to chemical composition of meat (water-75.74 and 75.90; intramuscular fat 1.31 and 1.10 and protein 21.76 and $21.83 \%$ ), technological properties as cooking losses and tenderness, organoleptic traits as total pigments and marbling, $\mathrm{pH}$ value and the muscle area of MLD (105.33 and $\left.103.47 \mathrm{~cm}^{2}\right)$. On the basis of the above results it can be said that addition of organic selenium into the diet resulted only in its accumulation in muscle tissue, but it does not affect the changes on its the most important chemical and technological characteristics. These data are important not only from the nutritional but also from the aspect of meat processing facilities and the purchase by the consumer.

Also, Elkolm et al. (1991) point out a linear increase in bovine muscle Se concentration where the dietary Se concentrations in the feed ranged from 0.03 to $0.40 \mathrm{mg} / \mathrm{kg} \mathrm{DM}$. In muscle tissue, the antioxidant functions of vitamin $\mathrm{E}$ and $\mathrm{Se}$ persist after slaughter and delay the onset of oxidation reactions in meat and meat products. These antioxidant functions are important because the oxidation of muscle lipids after slaughter can adversely affect the flavour and nutritive value of fresh, frozen, and cooked meat and meat products. Mentioned results demonstrate the justification for introduction of organically bound selenium in diets, since this is the most natural way for its introduction in the human organism. Manipulation of the animal's diet can result in increase in the concentration of some essential nutrients in milk and meat and could provide considerable benefits for human health. As consumers are becoming more conscious of the relationship between food and health, vitamin E, organically bound selenium, may prove to be "designer milk", "designer meat" or "functional food" with substantial potential and benefit.

\section{Conclusion}

In conclusion, based on the evidence presented herein, inclusion the organic selenium into finishing beef diet was much more effective than sodium selenite in increasing the concentration of Se in the muscle and internal organs indicating its better bioavailability. Having in mind that organically bound 
selenium is extremely important to the health of humans and animals its adding into animals diets is fully justified . It is a good and easy way of obtaining meat with functional food properties and it is possible to solve problems related to the selenium deficiency. Therefore, without the changing habits and traditions of various populations the consumer can buy the same animal-derived products meat, cook and consume them as usual. The only difference will be in the amount of specific nutrients delivered with such products.

\section{Acknowledgment}

Research was financed by the Ministry of Science and Technological Development, Republic of Serbia, project TR 31053.

\section{Proizvodnja goveđeg mesa obogaćenog organski vezanim selenom}

Lj. Sretenović, Ž. Novaković, M.M.Petrović, M. Todorović, V.Pantelić, S. Aleksić, M. Petričević

\section{Rezime}

$\mathrm{U}$ radu su ispitani efekti organskog i neorganskog selena $u$ obrocima junadi u tovu. Kao ozvor organskog selena korišćen je preparat Sell-Plex u kome je koncentracija selena iznosila $2000 \mathrm{mg} / \mathrm{kg}$ a izvor neorganskog selena bio je natrijumselenit. Ogled je izveden na Simentalskoj rasi goveda u završnoj fazi tova u slobodnom sistemu držanja i trajao je 60 dana.

Sadržaj selena u $m$. longissimus dorsi, jetri, slezini i bubrezima bio je značajno viši na ishranbenom tretmanu sa organskim selenom u odnosu na neorganski, što ukazuje na njegovu bolju bioiskoristivost. Urađena je disekcija polutke prema zvanično važećoj skali za klasifikaciju trupova odraslih goveda propisanoj od strane evropske zajednice. Dobijeni rezultati ukazuju da nije bilo razlike između tretmana sa organskim i neorganskim selenom u telesnoj masi grla pre klanja kao i glavnim karakteristikama polutke. Takođe, nije bilo razlike u udelu pojedinih tkiva u butu i trorebarnom isečku kao i ni u hemijskom sastavu i kvalitetu mesa u m. longissimus dorsi.

Imajući u vidu da je selen esencijalan mikroelement u ishrani a da organski vezan selen ima bolju bioiskoristivost $u$ odnosu na neorganski, njegovo uključivanje u obroke goveda i deponovanje u mesu i unutrašnjim organima je dobar i jednostavan način za dobijanje mesa sa svojstvima funkcionalne hrane koja treba da pored nutritivne vrednosti pozitivno utiče na zdravlje ljudi. Pošto su 
pojedini delovi planete Zemlje slabo opskrbljeni sa selenom ovo je najjednostavniji način da se reši problem njegovog deficita.

\section{References}

ANTUNOVIĆ Z., NOVOSELEC J., KLAPEC T., ČAVAR SUZANA, MIOČ, B, ŠPERANDA MARCELA. (2009): Influence of different selenium sources on performance, blood and meat selenium content of fattening lambs. Ital.J.Anim.Sci. 8: $163-165$.

AOAC (1990): Official methods of analysis. Association of Official Analytical Chemists. Washington, DC.

CLARK, L.C., B. DALKIN, A. KRONGRAD, G.F. COMBS, B.W. TURNBULL, E.H.SLATE, R. WITHERINGTON, J.H. HERLONG, E. JANOSKO, D. CARPENTER, C. BOROSSO, S. FALK, J. ROUNDER (1998): Decreased incidence of prostate cancer with selenium supplementation:results of a doubleblind cancer prevention trial. Brit. J. Urol. 81: 730-734.

COMBS, G.F. AND COMBS, S.F. (1986): The role of selenium in nutrition. Academic Press. Orlando.

COMMUNITY SCALE FOR THE CLASSIFICATION OF CARCASES OF ADULT BOVINE ANIMALS. www.office-elevage .fr/publications/classement/bovingb.pdf

EKHOLM, P., VARO, P., ASPILA, P., KOIVISTOINEN, P., SYRJALA-QVIST L.(1991): Transport of feed selenium to different tissues of bulls. British Journal of Nutrition. 66: 49-55.

LAWLER, L.T., TAYLOR, B,J., FINLEY,W. J., CATON, S.J. (2004): Effect of supranutritional and organically bound selenium on performance, carcass characteristics, and selenium distribution in finishing beef steers. J. Anim. Sci 82: 1488-1493.

LYONS, P.M., PAPAZYAN, T.T., SURAI F.P.(2007): Selenium in Food Chain and Animal Nutrition: Lessons from Nature Asian-Aust. J. Anim. Sci.. 20: 1135 1155 .

KNOWLES, O.S., GRACE,D.N., WURMS, K., LEE, J.(1999): Journal of Dairy Science. 82:429-437.

NICHOLSON, J. G., ST-LAURENT. A. MCQUEEN M., CHARMLEY E. R.(1991): The effect of feeding organically bound selenium and otocopherol to dairy cows on susceptibility of milk to oxidation. Can. J. Anim. Sci. 71: 135-143.

NRC (2001): National research council. Nutrient requirements of dairy cattle. Seventh revised edition, National Academy Press, Washington, DC. 
OMPRAKASH M., GOKULAKRISHNAN P., SAGAR C., RAJESH K.(2011): Meat as functional food - An approach towards healthier foods. Livestock Line. Vol.5: 8-10.

ORTMAN, K., PEHRSON, B. (1997): Selenite and selenium yeast as feed supplements for dairy cows. J. Vet. Med. (Ser. A) 44:373-380.

RICHARDS, J.C., BLALOCK, M.H., JACQUES, A.K., LOVEDAY D.H.(2011): Efficacy of feeding selenium enriched yeast to finishing beef cattle. The Professional Animal Scientist. 27:1-8

RULEBOOK ON THE QUALITY OF MEAT OF ANIMAL FOR SLAUGHTER, POULTRY AND WILDLIFE (1974): Službeni list SFRJ br. 34/74.

SIMEK J., CHLADEK G., KOUTNIK V., STEINHAUSER L. (2002): Selenium content of beef and its effect on drip and fluid losses. Animal Science Papers and Reports. 20: 49-53.

SRETENOVIĆ LJ., ALEKSIĆ ,S., RUŽIĆ-MUSLIĆ D., PETROVIĆ MILAN M., PANTELIĆ VLADA, BESKOROVAJNI R., ĐEDOVIĆ R.(2009): Dobijanje mleka i mesa sa osobinama funkcionalne hrane. Zbornik naučnih radova Instituta "PKB Agroekonomik"15: 67-78

SRETENOVIC, LJ. (2003): Primena savremenih biotehnologija u proizvodnji mleka. Simpozijum »Savremeni trendovi u mlekarstvu« Zlatibor, 124-128.

SRETENOVIĆ LJ., ALEKSIĆ S., PETROVIĆ P.M., MIŠČEVIĆ B. (2007): Nutritional factors influencing improvement of milk and meat quality as well as productive and reproductive parameters of cattle. Biotechnology in Animal Husbandry 23: $217-226$.

SRETENOVIĆ LJ., JOVANOVIĆ R., ADAMOVIĆ M., MILOŠEVIĆ M.(1999): Organically tied selenium in high yielding cows nutrition. Biotehnologija u stočarstvu. 69-76.

SRETENOVIĆ, LJ., ALEKSIĆ S., KATIĆ V. (2008): Značaj organski vezanog selena u ishrani životinja i ljudi. Simpozijum: »Stočarstvo, veterinarska medicina $\mathrm{i}$ ekonomika u proizvodnji zdravstveno bezbedne hrane«, Herceg Novi, 188-189.

STATISTICAL PACKAGE FOR THE SOCIAL SCIENCE (2006): SPSS., Ver.15.0.

SURAI, P. F. (2006): Selenium in Nutrition and Health. Nottingham University Press, Nottingham 